\title{
ANALISIS KESESUIAN LAHAN UNTUK PERUMAHAN MENGGUNAKAN SISTEM INFORMASI GEOGRAFIS DI KABUPATEN GARUT
}

\author{
Oleh: Iskandar Muda Purwaamijaya*), Torik Fikri**)
}

\begin{abstract}
Abstrak
Penelitian analisis kesesuian lahan untuk perumahan menggunakan sistem informasi geografis di Kabupaten Garut ini, merupakan penelitian untuk mengkaji diwilayah kecamatan mana saja yang sesuai untuk dijadikan lahan perumahan. Dengan hasil ini supaya terbentuk pembangunan yang berkelanjutan dimana dapat memenuhi kebutuhan masa sekarang tanpa membahayakan kemampuan generasi mendatang untuk memenuhi kebutuhannnya. Dengan menggunakan ketujuh tema dalam analisis fisik lingkungan ini diantaranya tema drainase, tema erosi, tema kemiringan/lereng, tema banjir, tema kedalaman efektif tanah, tema tekstur tanah, tema batuan kerikil ditambah tema administrasi supaya mempermudah dalam analisis sampai tingkat kecamatan. Penggunaan Software ArcView GIS 3.3 dalam analisis kesesuaian lahan. Metode penelitian yang digunakan adalah metode eksperimen dengan melakukan analisis spasial yang menghasilkan luasan wilayah kesesuaian 35,560\% dari luas wilayah Kabupaten Garut berada diwilayah yang baik, 32,827\% berada pada wilayah sedang, dan 31,613\% berada pada wilayah buruk untuk perumahan. Faktor kendala terbesar pada kawasan baik adalah drainase, kendala terbesar pada kawasan sedang selain erosi juga kemiringan lahan. Dimana kawasan hutan lindung termasuk pada wilayah sedang.
\end{abstract}

Kata kunci: Garut, SIG, Luasan sesuai untuk perumahan.

*) Dr. Ir. Drs. H. Iskandar Muda Purwaamijaya, MP., adalah dosen Jurusan Pendidikan Teknik Sipil UPI.

**) Torik Fikri, S.Pd., adalah alumni Jurusan Teknik Sipil UPI Tahun 2005.

\section{Pendahuluan}

Kepadatan penduduk di Kabupaten Garut telah mencapai 2,4 juta jiwa pada tahun 2006 memberikan konsekuensi pada perlunya penyediaan perumahan yang layak huni imbasnya diperlukan penyedian lahan untuk kebutuhan tersebut, maka dengan kepadatan penduduknya dengan ratio perbandingan 7 jiwa/ Ha kebutuhan akan perumahan harus tersediakan.

Hampir setiap aktivitas manusia melibatkan penggunaan lahan dan karena jumlah dan aktivitas manusia bertambah dengan cepat, maka lahan menjadi sumber yang langka. Tekanan jumlah penduduk dan terbatasnya luas lahan yang tersedia saat ini, secara tidak langsung meningkatkan upaya pemenuhan kebutuhan tempat 
tinggal dan mengakibatkan terjadinya proses perubahan penggunaan lahan yang cepat, keputusan untuk mengubah pola penggunaan lahan mungkin memberikan keuntungan dan kerugian yang besar, tidak dapat dipungkiri proses alih fungsi lahan secara sangat cepat berubah mulai dari kawasan hutan lindung, mata air, bantaran sungai, dan hulu sungai rentan akibat perubahan penggunaan lahan itu. Dampak dari perubahan itu tidak selalu menguntungkan, seperti meningkatnya luas lahan kritis yang akhirnya dapat mengakibatkan berbagai macam permasalahan.

Masalah penggunaan lahan merupakan salah satu masalah pembangunan lingkungan yang menimbulkan deviasi penentuan lokasi perumahan di atas sebidang lahan yang tidak sesuai dengan kapasitas kemampuan daya dukung lahan tersebut. Oleh karena itu pengalihan fungsi lahan di Kabupaten Garut menjadi sesuatu yang menarik untuk diteliti dan dikaji secara menyeluruh. Penyimpangan penggunaan lahan sebagai kawasan perumahan, menimbulkan gagasan untuk melakukan analisis kesesuaian lahan untuk perumahan menggunakan sistem informasi geografis.

\section{Pengertian Analisis Kesesuaian lahan}

Analisis kesesuaian lahan merupakan penyelidikan terhadap lahan untuk mengetahui keadaan yang sebenarnya, atau yang lebih lengkapnya penguraian suatu pokok atau berbagai bagiannya dan penelaahan bagian itu sendiri serta hubungan antar bagian untuk memperoleh pengertian yang tepat dan pemahaman arti keseluruhan, sedangkan lahan merupakan tanah terbuka, tanah garapan dalam artian yang masih mempunyai potensi sumberdaya lahan untuk berbagai penggunaannya (Anwar. Desi, Kamus Lengkap Bahasa Indonesia, 2003). Jadi pengertian kesesuaian lahan untuk perumahan adalah potensi lahan yang didasarkan atas kesesuaian lahan untuk penggunaan lahan untuk suatu bangunan. Lahan merupakan daerah permukaan bumi, termasuk seluruh elemen-elemen dari lingkungan fisik dan biologi didalamnya yang mempengaruhi penggunaan lahan, lahan menunjukan bukan saja tanah, tetapi termasuk terrain, iklim, hidrologi, vegetasi alami dan fauna, mencakup pula didalamnya perbaikan lahan seperti jaringan drainase (Hardjowigeno, 1999; FAO 1976).

Menurut Hardjowigeno (1999), kebijakan penggunaan tanah harus didasarkan pada berbagai aspek, yaitu: aspek teknis; aspek lingkungan; aspek hukum; aspek sosial; aspek ekonomi; dan aspek politik.

Lahan berhubungan dengan potensi sekarang, sehingga harus dipertimbangkan kemungkinan perubahan penggunaan lahan dan akibatnya. Keputusan untuk memilih suatu alternatif harus melalui perencanaan yang baik berdasarkan prinsip dan prosedur yang benar (Dirgahayu domiri, dede ;FAO, 1976). Penggunaan lahan berbagai aktifitas pada umumnya ditentukan oleh kesesuaian lahan yang ada di wilayah tersebut dan kesesuaian lahan bagi suatu areal dapat digunakan sebagai pegangan dalam pemanfaatan wilayah tersebut (Sitorus, 2004)

\section{Sistem Informasi Geografis (SIG)}


Sistem Informasi Geografi (SIG) merupakan sistem informasi yang dirancang menggunakan basis data yang memiliki referensi spasial atau berkoordinat geografi. Sebagai suatu sistem yang berbasis komputer, paling tidak ada empat pendekatan yang bisa dipergunakan untuk mendefinisikan dan membagi SIG, yaitu pendekatan proses (process oriented), pendekatan kegunaan alat (toolbox approach), pendekatan data base (database approach) dan pendekatan aplikasi (application approach)

Kekuatan SIG terletak pada kemampuan analisis yang bersifat memadukan data spasial dan atribut sekaligus. Fungsi analisis SIG menurut Aronoff (1993) dapat dikelompokan menjadi empat kategori, yaitu:

1) Fungsi pemanggilan, klasifikasi, dan pengukuran data,

2) Fungsi tumpang tindih (overlay function),

3) Fungsi tetangga (neigbourdhood), yang terdiri dari pencarian informasi (search), informasi garis pada polygon (line in polygon), informasi titik (point),

4) Fungsi jaringan atau keterkaitan

Ada beberapa cara untuk mengorganisasikan data dalam SIG, dalam hal ini pemilihan struktur data spasial sangat penting untuk menentukan rancangan suatu SIG. Pada kebanyakan pengoperasian SIG sangat jarang dilakukan pendesainan dari awal sampai jadi, tetapi pengetahuan tentang struktur data sangat penting. Pada dasarnya, pemakai harus waspada dalam pemilihan data karena akan berpengaruh langsung pada kecepatan pengolahan ataupun penyimpanan data. Perbedaan struktur akan sangat menentukan kecepatan kerja, seperti dalam kondisi perencanaan ataupun operasional, misalnya pengkonversian suatu struktur data kebentuk lain, baik karena suatu pekerjaan harus diselesaikan pada berbagai sistem ataupun pekerjaan hanya pada system yang ada. Disini pemahaman efek perbahan dari suatu sistem ke sistem lain sangat penting untuk diketahui.

\section{Analisis Data Spasial}

Pembangunan aplikasi sistem informasi geografik untuk analisis kesesuaian lahan perumahan, di peroleh dengan menggunakan kombinasi teknik analisis yang melalui prosedur :

a) Identifikasi kebutuhan pengguna untuk memperoleh luasan lahan untuk perumahan,

b) Studi pustaka mengenai kriteria lahan untuk perumahan,

c) Pembuatan model konseptual untuk pemasukan data, pemrosesan data dan pengeluaran hasil analisis,

Model analisis spasial kesesuain lahan untuk perumahan yang menggunakan fungsi irisan (intersect) dengan persamaan berikut:

$\mathrm{Y}=$ lokasi yang sesuai untuk perumahan

dengan:

$\mathrm{x}_{1}=$ peta drainase; $\mathrm{x} 2=$ peta erosi; $\mathrm{x} 3=$ peta kelerengan/miring; $\mathrm{x} 4=$ peta banjir; $\mathrm{x} 5=$ peta kedalaman efektif tanah; $\mathrm{x} 6=$ peta tekstur tanah; $\mathrm{x} 7=$ peta batuan .

Kriteria kesesuain lahan untuk perumahan atau tempat tinggal dapat dilihat pada Tabel 1. 


\section{Tabel 1. Kesesuaian Lahan Untuk Tempat Tinggal (Gedung)}

(USDA:1979)

\begin{tabular}{|l|c|l|l|}
\hline \multirow{2}{*}{ Sifat tanah } & \multicolumn{3}{|c|}{ Kesesuaian lahan perumahan } \\
\cline { 2 - 4 } & Baik & \multicolumn{1}{|c|}{ Sedang } & \multicolumn{1}{c|}{ Buruk } \\
\hline Drainase & D0 - D1 & D1 - D2 & D3 - D4 \\
Banjir & 00 & 00 & $01-04$ \\
Lereng & I0- I1 & I2 & I3 - I6 \\
Tekstur tanah & T5 - T4 & T4 - T3 & T2 - T1 \\
Batuan dan kerikil & B0 & B1 & B2 - B3 \\
Kedalaman efektif tanah & K3 & K2 & K0-K1 \\
Erosi. & Eo & E1 & E2 - E3 \\
& & & \\
\hline
\end{tabular}

Ketujuh parameter tersebut di atas merupakan faktor yang berpengaruh terhadap kelayakan fisik lahan untuk tempat tinggal (gedung). Pembobotan pada masing-masing tema mengacu pada pengaruh secara langsung terhadap konstruksi pondasi bangunan (Marina, 2008; Nakazawa, 1984; Chapin 1995) Perhitungan indeks kelayakan fisik menggunakan persamaan Indeks kelayakan fisik $=\mathrm{TwTr}+\mathrm{LwLr}+\mathrm{DwDr}+\mathrm{KwKr}+\mathrm{EwEr}+\mathrm{BwBr}+\mathrm{OwOr} . . .($ Marina 2009; Chapin, 1995) Dimana: $\mathrm{w}=$ bobot; $\mathrm{r}=$ nilai interval (rating); $\mathrm{T}=$ Tekstur tanah; $\mathrm{L}=$ Lereng; $\mathrm{D}=$ Drainase tanah; $\mathrm{K}=$ Kedalaman Efektif; $\mathrm{E}=$ Erosi ; $\mathrm{B}=$ Batuan; $\mathrm{O}=$ Banjir.

d) Pengumpulan data dari lapangan dan mengelompokan data berdasarkan jenis dan resolusi datanya.

e) Pembuatan model fungsional untuk pemasukan data, pemrosesan data dan pengeluaran hasil analisis.

1) Model fungsional input data meliputi:

\section{Tabel 2. Tekstur tanah (lapisan atas, lapisan bawah)}

\begin{tabular}{|c|l|c|c|c|}
\hline \multicolumn{2}{|l|}{} & Bobot & Nilai & BxN \\
\hline T1 & halus (liat,berdebu, liat) & 1 & 0 & 0 \\
\hline T2 & $\begin{array}{l}\text { agak halus (liat berpasir, } \\
\text { lempung liatberdebu, lempung } \\
\text { berliat, lempung liat berpasir) }\end{array}$ & 1 & 1 & 1 \\
\hline T3 & $\begin{array}{l}\text { sedang (debu, lempung } \\
\text { berdebu, lempung) }\end{array}$ & 1 & 2 & 2 \\
\hline T4 & agak kasar (lempung berpasir) & 1 & 3 & 3 \\
\hline T5 & kasar (pasir berlempung, pasir) & 1 & 4 & 4 \\
\hline
\end{tabular}

Tekstur tanah berhubungan dengan terdapat mineral liat yang terkandung dalam tanah. Tanah yang mengandung liat tipe 2:1 yang tinggi menyebabkan terjadinya retakan (cracking) dimusim kemarau. Tekstur tanah adalah perbandingan fraksi pasir, debu, dan liat dalam massa tanah. Fraksi adalah butir tunggal tanah dengan ukuran tertentu. 
Tabel 3. Lereng permukaan

\begin{tabular}{|l|c|c|c|c|c|}
\hline & $\%$ & & Bobot & Nilai & BxN \\
\hline $\mathrm{L}_{0}$ & $0-3$ & datar & 1 & 6 & 6 \\
\hline $\mathrm{L}_{1}$ & $>3-8$ & Landai/berombak & 1 & 5 & 5 \\
\hline $\mathrm{L}_{2}$ & $>8-15$ & $\begin{array}{c}\text { agak miring/ } \\
\text { bergelombang }\end{array}$ & 1 & 4 & 4 \\
\hline $\mathrm{L}_{3}$ & $>15-30$ & Miring/ berbukit & 1 & 3 & 3 \\
\hline $\mathrm{L}_{4}$ & $>30-45$ & agak curam & 1 & 2 & 2 \\
\hline $\mathrm{L}_{5}$ & $>45-65$ & Curam & 1 & 1 & 1 \\
\hline $\mathrm{L}_{6}$ & $>65$ & sangat curam & 1 & 0 & 0 \\
\hline
\end{tabular}

Curamnya lereng merupakan faktor yang menentukan dalam kegiatankegiatan yang perlu dilakukan untuk meratakan tanah tersebut. Hal tersebut menentukan banyaknya tanah yang harus digali di atas lereng dan ditimbunkan kebagian bawah lereng, pengelolaan tanah pada lereng yang curam membutuhkan lebih banyak tenaga dan modal dari pada daerah yang datar. Sebagai contoh, lebih banyak masalah dalam pengelolaan air dan erosi. Lereng juga mempengaruhi pembangunan bawah tanah, ataupun pembuatan jalan-jalan.

Tabel 4. Drainase

\begin{tabular}{|l|l|c|c|c|}
\hline & & Bobot & Nilai & BxN \\
\hline$D_{0}$ & Baik & 1 & 4 & 4 \\
\hline$D_{1}$ & Agak baik & 1 & 3 & 3 \\
\hline$D_{2}$ & Agak buruk & 1 & 2 & 2 \\
\hline$D_{3}$ & Buruk & 1 & 1 & 1 \\
\hline$D_{4}$ & Sangat Buruk & 1 & 0 & 0 \\
\hline
\end{tabular}

Drainase berhubungan dengan timbulnya bahaya genangan air, atau kemungkinan timbulnya kerusakan terhadap kerusakan terhadap konstruksikonstruksi dibawah tanah karena tata air tanah yang buruk. Drainase tanah menunjukan kecepatan meresapnya air dari tanah, atau keadaan tanah yang menunjukan lamanya dan seringnya jenuh air

Drainase tanah menunjukan kecepatan meresapnya air dari tanah, atau keadaan tanah yang menunjukan lamanya dan seringnya jenuh air, drainase tanah diklasifikasikan sebagai berikut:

$\mathrm{D}_{0}=$ Baik: tanah mempunyai peredaran udara baik, seluruh profil tanah dari atas sampai bawah berwarna terang yang uniform dan tidak terdapat bercakbercak.

$\mathrm{D}_{1}=$ Agak baik: tanah mempunyai peredaran udara baik, tidak terdapat bercakbercak berwarna kuning, coklat atau kelabu pada lapisan atas dan lapisan bawah.

$\mathrm{D}_{2}=$ Agak buruk: lapisan atas tanah mempunyai peredaran udara baik, tidak terdapat bercak-bercak berwarna kuning, kelabu atau coklat. Bercak-bercak terdapat pada seluruh lapisan bawah. 
$\mathrm{D}_{3}=$ Buruk: bagian atau lapisan atas (dekat permukaan) terdapat warna atau bercak-bercak berwarna kelabu, coklat dan kekuningan.

$\mathrm{D}_{4}=$ Sangat buruk: seluruh lapisan permukaan tanah berwarna kelabu dan tanah bawah berwarna kelabu atau terdapat bercak-bercak kelabu, coklat dan kekuningan

Tabel 5. Kedalaman efektif tanah

\begin{tabular}{|l|l|c|c|c|}
\hline \multicolumn{2}{|l|}{} & Bobot & Nilai & BxN \\
\hline K0 & Dalam $(>90 \mathrm{~cm})$ & 1 & 1 & 1 \\
\hline K1 & Sedang $(50-90 \mathrm{~cm})$ & 1 & 2 & 2 \\
\hline K2 & Dangkal $(25-50 \mathrm{~cm})$ & 1 & 3 & 3 \\
\hline K3 & Sangat dangkal $(<25 \mathrm{~cm})$ & 1 & 4 & 4 \\
\hline
\end{tabular}

Kedalaman efektif tanah adalah tebalnya lapisan tanah dari permukaan tanah sampai bahan induk atau sampai suatu lapisan dimana akar tanaman tidak dapat menembusnya. Lapisan tersebut dapat berupa liat yang keras. Kedalaman efektif 0$10 \mathrm{~cm}$ terlalu dangkal untuk usaha pertanian, sedangkan kedalaman 10-30 cm masih memungkinkan untuk tanaman semusim. Tanaman semusim cukup baik jika diusahakan pada tanah-tanah dengan kedalaman 30-60 cm, tetapi tanaman tahunan masih kurang baik. Tanaman semusim baik sekali jika diusahakan pada tanah berkedalaman efektif lebih dari $60 \mathrm{~cm}$, pada kedalaman $60-90 \mathrm{~cm}$ tanaman tahunan sudah cukup baik, yang paling baik untuk tanaman tahunan jika kedalaman efektif tanah lebih dari $90 \mathrm{~cm}$ (Hardjowigeno, 2007)

Kedalaman efektif akan menentukan kesesuaian lahan bagi berbagai jenis tanaman yang diusahakan pada suatu daerah. Kedalaman efektif dipengaruhi oleh jenis tanah dan keadaan erosi disuatu daerah. Faktor-faktor pembatas yang membatasi kedalaman efektif dapat berupa batuan, pasir, air dan lain-lainnya.

Tabel 6. Keadaan erosi

\begin{tabular}{|c|l|c|c|c|}
\hline & & Bobot & Nilai & BxN \\
\hline $\mathrm{E}_{0}$ & tidak ada erosi & 1 & 4 & 4 \\
\hline $\mathrm{E}_{1}$ & ringan $<25 \%$ lapisan atas hilang & 1 & 3 & 3 \\
\hline $\mathrm{E}_{2}$ & $\begin{array}{l}\text { sedang 25\% -75\% lapisan atas } \\
\text { hilang }\end{array}$ & 1 & 2 & 2 \\
\hline $\mathrm{E}_{3}$ & $\begin{array}{l}\text { Berat }>75 \% \text { lapisan atas hilang } \\
\text { s/d }<25 \% \text { lapisan bawah hilang) }\end{array}$ & 1 & 1 & 1 \\
\hline
\end{tabular}

Erosi adalah perpindahan partikel dari suatu tempat ketempat lain disebabkan adanya aliran permukaan (Hardjowigeno, 2007). Erosi adalah bentuk kerusakan tanah sebagai akibat dari hilangnya lapisan olah tanah (top soil). Kehilangan lapisan olah tanah ini di akibatkan oleh terjadinya pengangkutan olah tanah dari suatu tempat ketempat yang lain oleh media alam seperti angin atau air (Arsyad, 1983), faktor yang mempengaruhi erosi adalah curah hujan, keadaan tanah, panjang dan sudut lereng, vegetasi serta konservasi yang diterapkan. Lahan yang bervegetasi rapat, datar dengan curah hujan yang rendah mempunyai tingkat erosi 
jauh lebih rendah jika dibandingkan dengan lahan curam, tidak bervegetasi dan mempunyai curah hujan tinggi.

Besar/ kecil kadar jenis erosi penghanyutan dikelompokan sebagai berikut:

a) Erosi ringan; sebagian horison A (lapisan I) hilang dan di setempat-setempat terdapat parit-parit sebagai gejala timbulnya erosi parit $\left(\mathrm{E}_{1}\right.$ dan $\left.\mathrm{E}_{2}\right)$.

b) Erosi sedang; seluruh horison A (lapisan I) telah hilang dan banyak parit -parit sebagai akibat erosi parit $\left(\mathrm{E}_{3}\right)$

c) Erosi berat; sebagian besar solum tanah lenyap dan di setempat-setempat terdapat alur-alur sebagai gejala timbulnya erosi alur $\left(\mathrm{E}_{4}\right)$

Tabel 7. Kerikil/ batuan

\begin{tabular}{|l|l|c|c|c|}
\hline \multicolumn{2}{|l|}{} & Bobot & Nilai & BxN \\
\hline B0 & Tidak ada/ sedikit $0 \%$ - 15\% volume tanah & 1 & 4 & 4 \\
\hline B1 & sedang 15\% - 50\% volume tanah & 1 & 3 & 3 \\
\hline B2 & banyak 50\% - 90\% volume tanah & 1 & 2 & 2 \\
\hline B3 & sangat banyak $>90 \%$ volume tanah & 1 & 1 & 1 \\
\hline
\end{tabular}

Adanya hamparan batuan pada kedalaman 2 meter atau kurang, berpengaruh terhadap pembangunan konstruksi-konstruksi yang memerlukan penggalian tanah yang tidak terlalu dalam. Bahan kasar dapat berada dalam lapisan tanah atau dipermukaan tanah. Bahan kasar yang terdapat dalam lapisan $20 \mathrm{~cm}$ atau di bagian atas tanah yang berukuran lebih besar $2 \mathrm{~mm}$ di bedakan sebagai berikut:

a) Kerikil adalah bahan kasar yang berdiameter lebih besar dari $2 \mathrm{~mm}$ sampai 7,5 $\mathrm{cm}$ jika berbentuk bulat atau sampai $15 \mathrm{~cm}$ sumbu panjang bila berbentuk gepeng.

b) Batuan kecil adalah batuan kasar atau batuan yang berdiameter $7,5 \mathrm{~cm}$ sampai $25 \mathrm{~cm}$ jika berbentuk bulat, atau sumbu panjang berbentuk $15 \mathrm{~cm}$ sampai 40 $\mathrm{cm}$ jika berbentuk gepeng.

Tabel 8. Banjir

\begin{tabular}{|c|l|c|c|c|}
\hline \multicolumn{5}{|c|}{ Banjir } \\
\hline \multicolumn{1}{|c|}{} & Bobot & Nilai & BxN \\
\hline $0_{0}$ & Tidak pernah & 1 & 5 & 5 \\
\hline $0_{1}$ & Jarang & 1 & 4 & 4 \\
\hline $0_{2}$ & Kadang- kadang & 1 & 3 & 3 \\
\hline $0_{3}$ & Sering & 1 & 2 & 2 \\
\hline $0_{4}$ & Sangat sering & 1 & 1 & 1 \\
\hline
\end{tabular}

Banjir menunjukan tanah atau wilayah selama beberapa waktu tergenang air, disebabkan oleh hujan dan aliran dari tempat lain. Banjir (0) dinyatakan dengan jangka waktu banjir dalam setiap tahun.

$0_{0}=$ dalam periode satu tahun tanah tidak pernah tertutup banjir untuk waktu lebih dari 24 jam

$0_{1}=$ banjir yang menutupi tanah lebih dari 24 jam terjadi tidak teratur tertutup dalam periode kurang dari 1 bulan 
$0_{2}=2-6$ bulan banjir dalam satu tahun, selalu dilanda banjir yang lamanya lebih dari 24 jam

$0_{3}=>6$ bulan banjir dalam setiap tahun, secara teratur selalu dilanda banjir yang lamanya lebih dari 24 jam

2) Model fungsional output data:

Kriteria pembagian kelas kesesuaian lahan untuk perumahan dari hasil overlay adalah :

- Bobot $\mathrm{x}$ nilai kelas $=$ skor masing - masing tema

- Penjumlahan skor $=$ skor tekstur + skor drainase + skor banjir + skor batuan + skor lereng + skor kedalaman efektif + skor erosi

- $\quad$ Rentang kelas $=$ (nilai maksimum - minimum $)$

- Panjang interval $(\rho)=$ rentang kelas $/ 3$

Klasifikasi prediksi lokasi potensial untuk kawasan perumahan berdasarkan kelayakan fisik di Kabupaten Garut mengacu pada Klasifikasi untuk kawasan perumahan menurut Marina (2009) adalah:

- Klasifikasi lahan buruk untuk kawasan perumahan dengan nilai antara nilai minimum sampai dengan nilai minimum $+(\rho)$

- Klasifikasi lahan sedang untuk kawasan perumahan dengan nilai diatas nilai minimum $+(\rho)$ sampai dengan nilai minimum $+2(\rho)$

- Klasifikasi lahan baik sama dengan nilai diatas minimum $+2(\rho)$ sampai dengan nilai maksimum

f) Penyajian informasi peta tematik pada analisa kesesuaian lahan untuk perumahan yang sesuai berdasarkan distribusi frekuensi dengan 3 jumlah kelas yang telah dibuat dan dilakukan secara otomatis pada pemasukan database

g) Pembuatan model konseptual untuk pemasukan data, pemrosesan data dan pengeluaran hasil analisis kondisi existing penggunaan lahan untuk perumahan dilakukan dengan cara meng-overlaykan peta kesesuaian lahan untuk perumahan dengan meng-overlaykan ke-7 peta tematik.

Model konseptual analisis kesesuaian lahan untuk perumahan, selanjutnya di buat model fungsionalnya berupa pemberian nilai dan bobot bagi setiap kelas tema. Kelas tema diberi nilai dan bobot sama yaitu satu. Setelah model fungsional untuk melakukan analisis kesesuaian lahan untuk perumahan dibentuk maka dilanjutkan dengan implementasi model melalui proses konversi data grafis dan atribut yang bersifat analog menjadi digital ke dalam lingkungan komputer (digitasi on screen) (Marina, 2009)

Implementasi model analisis kesesuaian lahan untuk perumahan dalam bentuk digital memungkinkan para peneliti dan perencana untuk melakukan simulasi melalui modifikasi analisis statistik nilai-nilai tema yang dijadikan sebagai masukan untuk analisis kesesuaian data spasial (keruangan). Analisis kesesuaian lahan untuk perumahan dapat disajikan berupa tampilan peta-peta digital dengan penuh warna atau dalam bentuk tabel-tabel lokasi kesesuaian lahan untuk 
perumahan berdasarkan batas-batas administrasi kecamatan (berupa database sebagai informasi keadaan sebenarnya).

\section{Metodologi Penelitian}

\section{a. Metode Penelitian}

Metode penelitian adalah cara yang digunakan peneliti untuk menjawab tujuan yang ingin diketahui jawabannya. Metode yang digunakan dalam penelitian ini adalah metode eksperimen.

Sedangkan menurut datanya penelitian ini mengklasifikasikan menjadi 2 kelompok yaitu: data kualitatif yang digambarkan dengan kata-kata, selanjutnya data kuantitatif yang berwujud angka-angka hasil perhitungan atau pengukuran dapat diproses kembali dengan dijumlahkan, dibandingkan dengan jumlah yang diharapkan dan diklasifikasikan sehingga merupakan suatu susunan urut data (array), selanjutnya dibuat tabel dan diperoleh persentase, kemudian sesudah terdapat hasil akhir lalu diinterpretasikan dengan kalimat yang bersifat kualitatif.

Model yang dibuat adalah model empiris yaitu model yang menjelaskan mengenai variabel yang diteliti dan diimplementasikan melalui model sistem informasi geografis berbasis komputer. Dalam penelitian ini model empirisnya adalah dalam bentuk kajian analisis kesesuain lahan untuk perumahan hasil dari analitis data dalam jumlah ketujuh tema menggunakan sistem informasi geografis berbasis komputer (overlay yang di lanjutkan dengan intersection ke-7 tema peta) di tambah peta administrasi wilayah untuk mempermudah mengetahui daerah mana saja yang sesuai untuk perumahan. Model empirik atau relasional yang digunakan dalam penelitian ini menggunakan perangkat lunak ArcView release 3.3 yang merupakan perangkat lunak desktop SIG dan pemetaan yang dikembangkan oleh ESRI ( Enviromental System Research Institute, Inc). ArcView adalah perangkat lunak yang banyak dipakai untuk mengolah data spasial, selain itu juga mampu untuk menyediakan suatu liputan analisis pada sekumpulan gambar atau peta yang berada dalam lingkup ArcView. Penyimpanan data-data dalam ArcView disimpan dalam directory/folder, file, juga record, penyimpanan data-data dalam ArcView disimpan dalam beberapa theme, jadi setelah proses data raster (scanner) ke data vector, data-data peta digital yang berbentuk file di rubah menjadi beberapa theme (tematik). Setelah data-data tersebut berada di ArcView dilakukan proses pendigitasian juga pengeditan yang bertujuan untuk pemeriksaan dan perbaikan data (memanipulasi data/pembaruan data), sekaligus melakukan pemasukan data dan pemberian tekstual

ArcView dapat menyajikan segala macam informasi dengan banyak cara yang dituangkan, arcView menggunakan beberapa tabel dan kertas kerja untuk memanipulasi data:

1) Bekerja dengan view dengan menambahkan beberapa theme,

2) Menambah, mengurangi, memanipulasi theme,

3) Menyimpan data point, line, polygon semuanya adalah satu kesatuan dalam membentuk sebuah peta, 
Analisis spasial adalah analisis yang berhubungan dengan georeferensi ruang dan waktu. Peta juga menunjukan lokasi-lokasi bencana alam, jenis tanah, tema erosi dan yang lainnya. Dengan menambah text dan legenda, sebuah peta akan terasa hidup dan dapat menceritakan kondisi sebuah lokasi.

Sistem koordinat digunakan sebagai petunjuk lokasi, setiap point ditampilkan dengan lokasi $\mathrm{X}$ dan $\mathrm{Y}$, koordinat ini biasanya dalam bentuk longitude dan latitude (garis bujur dan garis lintang) atau berupa system koordinat proyeksi UTM (absis, ordinat, dan nomor zone).

Model adalah ringkasan kenyataan. Model juga merupakan pemaparan formal bagian-bagian utama masalah, karena bagian-bagian utama masalah yang kita tetapkan merupakan pusat kajian sistem yang kita bangun, maka model pengertiannya adalah pemaparan formal sistem dengan pusat kajian tertentu. Model dapat berupa model fisik, atau verbal walaupun beberapa model ditujukan bagi model kata-kata tetapi bahasa biasanya memiliki makna ganda (Jeffers, 1987). Model empiris atau korelatif dibangun untuk menggambarkan dan meringkas hubungan tanpa melihat secara terperinci mekanisme yang terjadi dalam sistem dunia nyata. Tujuan model empiris adalah untuk memprediksi atau memperkirakan bukan untuk menjelaskan, selain itu juga kita akan menganalisis, menafsirkan dan menginterpretasikan hasil-hasil pemrosesan program, menggunakan prosedur umum yang sama sehingga dapat kita gunakan untuk hasil di dunia nyata. Secara umum model empirik dari kesesuian lahan untuk perumahan berwawasan lingkungan di Kabupaten Garut

\section{b. Variabel Penelitian}

Variabel penelitian adalah suatu atribut atau sifat atau aspek dari orang maupun obyek yang mempunyai variasi tertentu yang ditetapakan oleh peneliti untuk dipelajari dan di tarik kesimpulannya (Sugiono 2001;20).

Dalam penelitian ini variabelnya adalah analisis kesesuaian lahan untuk perumahan dari hasil penjumlahan tujuh tema yaitu: drainase; kelerengan; kedalaman efektif; tekstur tanah; banjir; erosi; kerikil dan batuan

\section{c. Paradigma Penelitian}

Untuk menjabarkan variabel penelitian, dapat dilihat di dalam paradigma penelitian. Menurut Sugiono (2001:24), bahwa "Paradigma penelitian dapat di artikan sebagai pandangan atau model, atau pola pikir yang dapat menjabarkan pelbagai variabel yang akan diteliti kemudian membuat hubungan antara satu variabel dengan variabel yang lain, sehingga akan mudah dirumuskan masalah penelitiannya, pemilihan teori yang relevan, rumusan hipotesis yang diajukan, model atau strategi penelitian, teknik analisa yang akan digunakan serta kesimpulan yang diharapkan"

\section{d. Objek dan Lokasi Penelitian}

Objek penelitian analisa kajian lahan untuk perumahan berwawasan lingkungan di Kabupaten Garut menggunakan teknologi sistem informasi geografis 
adalah kondisi wilayah Kabupaten Garut. Kondisi aktual wilayah Kabupaten Garut diperoleh melalui pengumpulan data tekstual dan spasial untuk dianalisis bagi kepentingan analisa kajian lahan untuk perumahan berwawasan lingkungan. Batasan area tidak hanya bersifat batas ekologis saja yang ditonjolkan tetapi juga batas administrasi sampai tingkat Kecamatan sehingga hasil analisis dapat diimplementasikan di lapangan baik untuk kegiatan perencanaan maupun pemantauan hasil-hasil pembangunan.

Objek penelitian adalah di Kabupaten Garut yang terletak antara $6^{0} 56^{\prime} 49^{\prime \prime}$ $7^{0} 45^{\prime} 00^{\prime \prime}$ lintang selatan dan $107^{0} 25^{\prime} 8^{\prime \prime}$ - 108 $8^{\prime} 30^{\prime \prime}$ bujur timur. Kabupaten Garut memiliki ketinggian yang bervariasi antara wilayah tertinggi dipuncak gunung. Wilayah yang berada di ketinggian diantara 100-1500 m dpl (diatas permukaan laut). Luas wilayah Kabupaten Garut mencapai 3.044.544.200,527 $\mathrm{m}^{2}$.

\section{e. Data dan Sumber data}

Jenis data yang dikumpulkan terdiri dari dua jenis yaitu: data grafis berupa peta-peta data pokok pembangunan Kabupaten Garut berskala 1:100.000 dan statistik Kabupaten Garut berdasarkan batas administrasi kecamatan tahun 2006.

Data grafis berupa peta-peta dikumpulkan dari Badan Perencanaan Pembangunan Daerah (BAPPEDA) Kabupaten Garut hasil interpretasi citra satelit oleh Badan Koordinasi Survei dan Pemetaan Nasional (Bakosurtanal) yang dikonversikan menjadi data vector digital format ArcView. Peta-peta yang dikumpulkan meliputi: peta drainase, peta banjir, peta lereng, peta tekstur tanah, peta batuan, peta kedalaman efektif tanah, peta erosi, yang kemudian ditumpangtindihkan dengan tema-tema pada peta data dan peta administrasi untuk mempermudah mengetahui daerah-daerah kajian. Data statistik dikumpulkan dari BAPPEDA Kabupaten Garut hasil survei statistik Biro Pusat Statistik (BPS) Kabupaten Garut.

\section{f. Populasi dan Sampel}

Populasi dalam penelitian ini adalah karakteristik wilayah Pemerintah Kabupaten Garut, yang secara administratif luasnya mencapai 3.044.544.200,527 $\mathrm{m}^{2}$. dengan 42 kecamatan dan 424 desa/kelurahan. Sedangkan sampel penelitian diambil dari seluruh populasi yang ada, karena data yang tersedia memungkinkan populasi juga menjadi sampel penelitian. Sampel penelitian yang mengambil populasi penelitian juga lebih menggambarkan hasil penelitian lebih akurat.

\section{g. Teknik Pengumpulan Data}

Teknik pengumpulan data merupakan langkah yang paling strategis dalam penelitian. Dalam pengumpulan data diperlukan juga instrumen atau alat yang digunakan sebagai pengumpul data selain studi pustaka, juga melakukan wawancara dengan berbagai ahli di bidangnya yang nantinya digunakan untuk memperoleh bobot pada penilaian skor untuk mengetahui sesuai tidaknya lahan yang dijadikan obyek penelitian di Kabupaten Garut yang diperuntukan untuk perumahan. 
Studi literatur merupakan teknik pengumpulan data dengan cara membaca dan mempelajari data dari buku-buku, laporan, majalah dan media cetak lainnya yang berhubungan dengan konsep dan permasalahan yang diteliti.

\section{h. Tahap-Tahap Penelitian}

Penelitian aplikasi teknologi inderaja dan Sistem Informasi Geografik (SIG) untuk analisa kesesuaian lahan untuk perumahan di Kabupaten Garut melalui tahap-tahap, yaitu:

1) Identifikasi kebutuhan pengguna untuk mengevaluasi analisa kesesuaian lahan untuk perumahan.

2) Studi pustaka mengenai kriteria evaluasi analisa kesesuaian lahan untuk perumahan.

3) Pembuatan model konseptual untuk pemasukan data, pemrosesan data dan pengeluaran hasil analisis.

4) Pengumpulan data dari lapangan dan mengelompokan data berdasarkan jenis dan resolusi datanya.

5) Proses konversi data analog menjadi digital.

6) Proses kodifikasi data spasial dengan data tekstual agar bergeoreferensi.

7) Proses analisis terintegrasi antar analisis spasial dengan analisis statistik yang diadaptasikan dengan kemampuan perangkat lunak dan perangkat keras yang digunakan.

8) Pembangunan aplikasi sistem informasi geografis dalam analisis kesuaian lahan untuk perumahan yang berwawasan lingkungan.

\section{Hasil Penelitian dan Pembahasan}

a. Analisis Kesesuaian Lahan Untuk Perumahan Menggunakan Sistem Informasi Geografis

Analisis spasial menggunakan Sistem Informasi Geografis berbasis komputer untuk memperoleh lahan yang sesuai untuk perumahan di kecamatan-kecamatan Kabupaten Garut yang ditentukan berdasarkan: peta drainase, peta keadaan erosi, peta kemiringan atau lereng permukaan tanah, peta banjir, peta kedalaman efektif tanah, peta tekstur tanah, peta kerikil dan batuan. Gambar peta lokasi studi dan peta-peta tematik input disajikan pada lampiran 1 sampai 7.

Selisih skor terbesar dan terkecil hasil analisis sebagai berikut:

- Bobot $\mathrm{x}$ nilai kelas $=$ skor masing - masing tema

- Penjumlahan skor $=$ skor drainase + skor erosi + skor lereng + skor banjir + skor kedalaman efektif + skor tekstur + skor kerikil dan batuan $=29$

- $\quad$ Rentang kelas $=($ nilai maksimum - minimum $)=20$

- $\quad$ Panjang interval $(\rho)=$ rentang kelas $/ 3=7$

Klasifikasi prediksi lokasi potensial untuk kawasan perumahan berdasarkan kelayakan fisik di Kabupaten Garut mengacu pada Klasifikasi untuk kawasan perumahan menurut Marina (2009) adalah:

- Klasifikasi lahan buruk untuk kawasan perumahan dengan nilai antara nilai minimum sampai dengan nilai minimum $+(\rho)=14$ 
- Klasifikasi lahan sedang untuk kawasan perumahan dengan nilai diatas nilai minimum $+(\rho)$ sampai dengan nilai minimum $+2(\rho)=23$

- Klasifikasi lahan baik sama dengan nilai diatas minimum $+2(\rho)$ sampai dengan nilai maksimum $>24-29$

Selisih skor terbesar dan terkecil hasil analisis adalah 20 atau sama dengan rentang kelas. Selanjutnya adalah penentuan kesesuaian lahan untuk perumahan yang dibagi menjadi tiga kelas daerah dengan panjang interval $(\rho)$ sebesar 9 yaitu:

1) Daerah baik untuk kawasan perumahan dengan nilai antara 24 sampai dengan 29

2) Daerah sedang untuk kawasan perumahan dengan nilai 14 sampai dengan 23 , dan

3) Daerah buruk untuk kawasan perumahan dengan nilai 9 sampai dengan 14

Hasil analisis spasial menggunakan Sistem Informasi Geografis berbasis komputer untuk memperoleh kawasan yang sesuai untuk perumahan di kawasan Kabupaten Garut.

Tabel 9. Persentase luas lahan untuk perumahan

\begin{tabular}{|l|l|}
\hline Zona & Persentase \\
\hline Baik & 35.56 \\
\hline Sedang & 32.83 \\
\hline Buruk & 31.61 \\
\hline
\end{tabular}
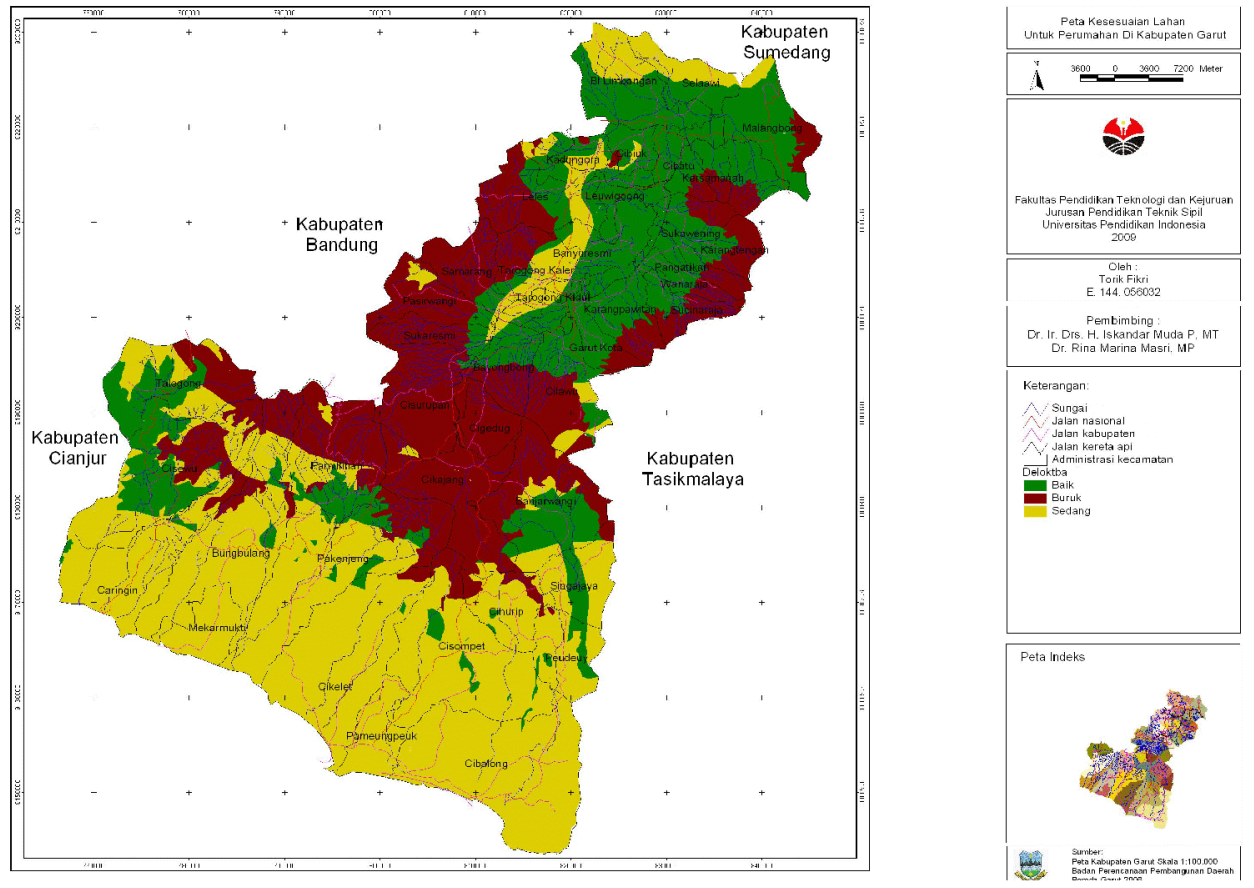

Gambar 1. lahan kesesuaian untuk perumahan hasil analisis spasial di Kabupaten Garut 
Hasil analisis spasial menunjukan bahwa lahan di setiap kecamatan daerah Garut utara menunjukan lahan yang baik untuk perumahan dan sebagian kecil tersebar diidaerah Garut bagian tengah, dimana ada beberapa faktor kendala untuk dibangunkan daerah perumahan. Faktor kendala pada daerah perumahan baik adalah parameter drainase yang agak buruk, yaitu kondisi tanah dengan tingkat bahaya genangan air yang tinggi sehingga tanah menjadi jenuh air, dimana nilai 2 untuk parameter drainase dari skala pengukuran 0 sampai 4 yang mana bisa dikatakan kategori sedang pada parameter drainase untuk perumahan. Evaporasi akan terhambat pada bagian tengah dari bangunan karena tanah tertutup bangunan sehingga dapat menyebabkan tanah dibagian tepi lebih cepat kering daripada bagian tengah bangunan. Hal ini dapat menyebabkan perbedaan pengerutan maupun kekuatan tanah sehingga sering terjadi penurunan pada bagian tengah menimbulkan keruntuhan. Untuk menghindari adanya kerusakan bangunan yang disebabkan oleh pengerutan tanah hendaknya pondasi dibangun lebih dalam atau sampai pada kedalaman batuan hingga tidak terrjadi proses pengerutan tanah.

Faktor kendala terbesar di daerah sedang untuk perumahan selain parameter drainase juga parameter erosi suatu tanah. Dimana erosi tanah terjadi akibat hancurnya partikel pecah atau terhancurnya (detached) tanah yang kemudian dipindahkan ketempat lain oleh kekuatan air, angin atau gravitasi. Erosi dapat terjadi akibat kegiatan manusia yang mengganggu keseimbangan alam salah satunya penggundulan hutan didaerah-daerah pegunungan. Selain itu, parameter kemiringan lereng diatas $15 \%$. Pembangunan perumahan pada kemiringan lereng relative curam tanpa dilakukan pengamanan lebih lanjut dapat menyebabkan tanah longsor mungkin juga erosi. Kelongsoran atau erosi tanah dapat terjadi pada lereng dengan material tanah yang bersifat sensitife terhadap perubahan kondidi air tanah. Kelongsoran atau erosi tanah awal terjadi pada bagian lereng diatsnya. Kelongsoran lanjutan akan terjadi jika proses pembebanan baik mekanik maupun adanya rembesan air hujan menyebabkan berkurangnya kuat geser tanah maupun adanya rembesan air hujan menyebabkan berkurangnya kust geser tanah sehingga stabilitas lereng dalam kondisi kritis. Hal ini dapat dihindari selain membangun tembok penahan tanah adalah mengimplementasikan persyaratan teknis koefisien dasar bangunan sebesar 15\%-25\% dari luas tanah (Building Cooverage Ratio) atau perbandingan luas yang terbangun dengan luas perbandingan terbuka (hijau) yang disyaratkan dari luas terbangun (departemen perumahan dan permukiman), membangun ruamah konsep eco-architecture dan penanaman vegetasi pada teras bangku atau teras tangga.

Selain parameter yang dijadikan pengambilan kebijakan dalam pembangunan suatu perumahan yang dipaparkan juga pengambilan keputusan untuk membangunkan suatu perumahan ada kendala yang tetap harus dipegang, misal dari hasil analisis untuk perumahan tersebar bahwa didaerah hutan lindung menunjukan kawasan baik untuk perumahan atau sedang. Pada kadar ini sebaiknya perumahan tidak dibangun sebab meskipun memberikan dampak posistif bagi perkembangan suatu wilayah namun pada prinsipnya pada kawasan hutan lindung 
maupun sejenisnya perkembangan perumahan harus dibatasi dan bila perlu kegiatan perumahan pada kawasan hutan lindung tidak ada.

\section{Penutup}

Kesimpulan dari penelitian analisis kesesuaian lahan untuk perumahan menggunakan sistem informasi geografis di Kabupaten Garut adalah:

1) Luas lahan perbandingan antara lahan yang baik, sedang, dan buruk untuk dibangunkan perumahan mencapai 35,560\% dari luas Kabupaten Garut berada pada daerah yang baik dijadikan untuk dibangunkan atau dikembangkan untuk perumahan, $32,827 \%$ berada pada kawasan yang sedang untuk dibangunkan atau dikembangkan perumahan dan $31,613 \%$ berada pada kawasan yang buruk untuk dijadikan perumahan khusus untuk kawasan buruk direkomendasikan untuk tidak dijadikan perkembangan perumahan hal ini cocok untuk pertanian, perkebunan dan di jadikan hutan lindung atau sejenisnya untuk tema masukan sama.

2) Luas perbandingan antara kawasan yang baik dan sedang untuk perumahan ada beberapa kendala dari parameter-parameter diantaranya di kawasan baik untuk perumahan ada kendala drainase tanah, dan pada kawasan sedang selain drainase, erosi juga kelerengan. Pada kawasan sedang untuk dikembangkan perumahan terbentur dengan kendala adanya kawasan hutan lindung maka (dari hasil analisis) khusus untuk kawasan lindung perkembangan perumahan sebaiknya dibatasi bila perlu tidak ada kegiatan di hutan lindung selain dapat merusak juga dapat tidak seimbangnya lingkungan, maka sebaiknya bila dikawasan hutan lindung ada kegiatan perumahan penduduk diupayakan dipindahkan dengan tetap memperhatikan kesejahteraan penduduk tidak berkurang. Perkembangan pada kawasan buruk maupun sedang (kategori hutan lindung dan sejenisnya) bila dikembangkan suatu perumahan dapat berdampak pada keamanan dan kenyamanan pada penduduk, sekiranya pada kawasan ini dapat dimanfaaatkan untuk tanaman perkebunan, pertanian juga dimanfaatkan untuk hutan produksi.

3) Pilihan kebijakan-kebijakan untuk mendukung pembangunan berkelanjutan di kawasan Kabupaten Garut untuk kesesuaian perumahan, adalah

a) kebijakan yang terkait dengan pengendalian laju pembangunan perumahan dengan memanfaaatkan instrument teknologi citra satelit dan sistem informasi geografis khususnya dalam mengimplementasikan penyempuranaan penataan untuk perumahan yang baik, aman dan nyaman serta mengimplementasikan instrumen perundangan.

b) Kebijakan standar penggunaan lahan untuk perumahan dimana dapat menekan laju pembangunan perumahan yang efektif, efisien dan dapat mengimplementasikan persyaratan teknis koefisien dasar bangunan sebesar $15 \%-25 \%$ dari luas tanah (Building Cooverage Ratio).

c) Kebijakan alokasi lahan kawasan sedang untuk perumahan diharapkan tetap pada fungsinya (khusus untuk kawasan hutan lindung) dilindungi secara ketat dan menghentikan kegiatan konversi lahan kawasan lindung 
menjadi lahan perumahan yang lebih cepat, tepat, mudah dan murah dengan memanfaatkan kemajuan ilmu pengetahuan serta teknologi.

\section{Daftar Pustaka}

Analisis Mengenai Dampak Lingkungan 2003. BPLHD propinsi Jawa Barat

Anwar, Desi 2003, Kamus Lengkap Bahasa Indonesi, Surabaya: Amelia

Bappeda 2005, Revisi RTRW Kabupten Garut

Dirgahayu, DD 2003, Evaluasi Konversi Lahan Sawah Dengan Menggunakan SIG di Kabupten Bekasi, Jawa Barat

Iman, M. Imam 2008. Konversi lahan Mengancam Ketahanan Pangan. [Online]. Tersedia: http//www.google.com. [24 oktober 2008)

Marina, RM 2009. Kajian Perubahan Perilaku Zona Buruk Untuk Perumahan SPs. IPB Bogor

Nurlambang, Triarko 2008. Pendekatan Tinjauan Sosial Ekonomi Dalam Kajian Kerusakan Lahan/Tanah [Online]. Tersedia: http//www.google.com. [24 oktober 2008)

Prahasta, Eddy 2007, Tutorial ArcView Sistem Informasi Geografis. Bandung: Informatika

Prahasta, Eddy 2004, Tool dan plug-Ins Sistem Informasi Geografis. Bandung: Informatika

Purwaamijaya, I.M. 2008. Deskripsi silabus dan hand out ilmu ukur tanah. Bandung: Universitas Pendidikan Indonesia

Ritung, Sofyan. dkk. 2007. Panduan Evaluasi Kesesuaian Lahan. Balai Penelitian Tanah dan World Agroforestry Centre.

Sudjana (2002). Metoda Statistika, Bandung Tarsito

Surati jaya, I Nengah 2002, Aplikasi Sistem Informasi Geografis Untuk Kehutanan. Bogor : Institut Pertanian Bogor.Fakultas Kehutanan.

Tahir, Amiruddin. 2002. Analisis Kesesuaian Lahan dan Kebijakan Pemanfaatan Ruang Kawasan Pesisir Laut Balikpapan. Jurnal Pesisir dan Lautan. IV No. III, 2002

Wayan. Wardana, I. 2004. GeoKumpatasi ( Komputer Untuk Geologi). Jurusan Teknik Geologi, Fakultas Teknik UGM.

Wirosuprojo, Supratman 2005. Klasifikasi Lahan Untuk Perencanaan Penggunaan lahan di Kabupaten Sleman DIY. Forum Perencanaan Pembangunan.

Wongsotjitro, Soetomo 1991. Ilmu Ukur Tanah. Yogyakarta: kanisius ,2004 Kajian Lingkungan Hidup, Jakarta \{Online). 